\title{
Linking operations, marketing and environmental capabilities and diversification to hotel performance: A data envelopment analysis approach
}

\begin{abstract}
This study examines the impacts of marketing capability, operations capability, environmental capability and diversification strategy on performance of hotel industry in the UK. We conceptualize these impacts by drawing on the resource-based-view of a firm as the theoretical underpinning. We use the financial archival data and information obtained from websites. We use content analysis, regression analysis and Data Envelopment Analysis (DEA). Our results show that operations capability and environmental capability have significant positive effects on performance, marketing capability has a significant negative impact but diversification strategy does not impact on performance. Additionally, there is no evidence of the moderating effects of efficiency on these impacts. Our study suggests that hotel industry in the UK ought to focus on developing operations and environmental capabilities especially by exploiting the synergies between them but reduce excessive reliance on marketing. This paper makes two important contributions to the literature. First, it applies a framework linking the three capabilities (operations, marketing and environment) and diversification to the specific case of the hotel industry. Second, unlike similar previous studies, ours is the first to incorporate environmental capabilities in the analysis.
\end{abstract}

Keywords: Performance, resource-based-view, content analysis, data envelopment analysis, operations capability, marketing capability, environmental capability, diversification. 


\section{Introduction}

The hotel industry is fast developing and it is very competitive (Sargeant and Mohamad, 1999). This sector is also well researched in the academic literature; there are studies that explored the links among various aspects of performance, such as market orientation, strategic planning, environmental management and financial measurements in the UK hotel industry (Sainaghi, 2010).

Capabilities of a firm to efficiently organize its functions (e.g., marketing, operations, etc.) in general have positive impact on its performance. A number of studies have investigated how capabilities have affected a firm's performance. Some of the studies have employed the resourcebased-view (RBV) of a firm as their theoretical base. Efficient operations capability can create competitive advantage (Tan et al., 2007; Ramanathan and Gunasekaran, 2014). Many researchers claim that marketing capability has significant positive effect on firms' financial performance (Kumar et al., 1998; Narver and Slater, 1990). Additionally, firms use superior environmental capability management to comply with the corporate social responsibility commitment, build reputation for natural environmental services, and earn profit on performance (Judge and Douglas, 1998; Klassen and McLaughlin, 1996). Furthermore, service diversification has two potential impacts on a company's overall performance, positive (Bettis, 1981; Chatterjee and Wernerfelt, 1991) or negative (Chakrabarti et al., 2007). Nath et al. (2010) measure the impacts of functional capabilities (including marketing capability and operations capability) and diversification strategy on financial performance for the UK based logistics industry.

Though there are several studies that explored the impacts of capabilities on a firm's performance in general, unfortunately, there is no study that attempted a similar investigation for the specific case of the hotel industry, especially in the UK. Our study aims to fill this gap by 
drawing on the RBV theory. Given the growing importance of the tourism and the hospitality industry in the global economy, such a study will provide useful insights to develop hotel business strategies. Our study not only adapts the framework (linking operations and marketing capabilities, and diversification) suggested in previous studies, but also extends the framework by adding environmental capability in the analysis for the UK hotel industry. In line with the theme of this special issue, we use secondary data for the analysis.

Thus, the objective of this paper is to investigate the impacts of marketing capability, operations capability, environmental capability and service diversification on hotel financial performance in the UK. We further study whether hotels that are more efficient in utilizing their resources are able to register better links between capabilities and performance. Relevant data for the analysis have been collected using financial databases and using content analysis of annual reports/ corporate social responsibility reports/web pages of hotels. The capabilities are assessed using an efficiency measure of Data Envelopment Analysis (DEA). The impacts and the moderating role of efficiency are investigated using regression analysis.

We believe that our paper makes two important contributions to the literature. First, it applies a framework linking the three capabilities (operations, marketing and environment) and diversification to the specific case of the hotel industry. Second, unlike similar previous studies, ours is the first to incorporate environmental capabilities in the analysis.

The rest of the paper is organized as follows: In Section 2 the relevant literature is described and research hypothesis are developed. The research methods, data and measurements are explained in Section 3. Results and data analysis are discussed in Section 4. Section 5 summarizes 
and discusses the results. Conclusions, limitations and further research opportunities are detailed in the final section.

\section{Literature review and hypothesis development}

In this section, we first provide a synopsis of the resource-based view (RBV) theory linking resources, capabilities and their impacts on firm performance. We then discuss relevant literature specific to marketing capabilities, operational capabilities, environmental capabilities, and diversification strategy, and develop our research hypothesis based on the literature review.

\subsection{The Resource-Based-View (RBV) of a firm}

The Resource-Based-View (RBV) has been used widely by many theorists in the development and deployment of resources (Amit and Schoemaker, 1993;Barney and Zajac, 1994; Kraaijenbrink et al., 2010; Lei et al., 1996). Wernerfelt (1984) has first proposed the RBV of a firm and considered the firm as a bundle of resources and capabilities. A resource is composed of tangible and intangible components. For example, equipment is tangible component and technology knowhow is intangible component (Amit and Schoemaker, 1993). The resources, such as competencies, with potential to create value can be considered as a source of competitive advantage. Capabilities are the abilities of a firm to be able to use resources to achieve a desired outcome. Resources and capabilities should not only be valuable, rare, inimitable, and nonsubstitutable (VRIN), but also enable the value to be created (Barney, 1991).

A very useful feature of the RBV is that it helps explain why some firms perform better than others by explicitly looking at the internal resources and capabilities as sources of sustainable competitive advantage (Kraaijenbrink et al., 2010). It explains that the way a firm uses its available resources, uses its existing capabilities to the best level possible, generate new knowledge that 
cannot be easily imitated, create immobility of competitive capability-producing resources, and bring inimitability to its resource-capability framework (Kraaijenbrink et al., 2010; Peteraf,1993; Song et al., 2007). In this paper, we develop our conceptual framework and hypotheses based on the links between resource-capabilities (operations, marketing and environmental) and financial performance of a firm, as suggested by the RBV.

Given the interesting insights obtained using RBV, this theory has been applied to investigate firms' performance (e.g., Dutta et al., 1999), and the research reveals that capabilities affect the firm performance significantly. Dutta et al. (1999) have described the capability of a firm as ability to deploy available resources (inputs) to achieve desired objectives (outputs). RBV has also been used in the literature to show how a firm can diversify by expanding the resources into new product markets or new geographic locations (Fang et al., 2007). Hart (1995) has related a firm's business with its natural environment to achieve competitive advantage to the firm. It is predicted that the natural resources will be limited in the future, thus the optimal environmental management can form a sustainable competitive advantage for a firm (Greenley and Foxall, 1997). Finally, there is a general view in the literature (Ramanathan, 2010), mainly based on the RBV theory, that firms' efficiency acts as a moderator of the impacts of capabilities on performance; firms that are efficient in utilizing their available resources will be able to register better links between capabilities and performance.

\subsection{Capabilities and relationship with performance}

In this paper, using RBV as the theoretical backdrop, we explore how marketing capability, operations capability, environmental capability and diversification strategy influence hotel 
performance, and also explore the moderating role of efficiency on these relationships. The conceptual framework governing our study is sketched in Figure 1. The relationships shown in the figure in the form of hypotheses $\mathrm{H} 1 \mathrm{a}-\mathrm{H} 4 \mathrm{a}$ and $\mathrm{H} 1 \mathrm{~b}-\mathrm{H} 4 \mathrm{~b}$ will be discussed in the next few sections.

Figure1: Conceptual framework

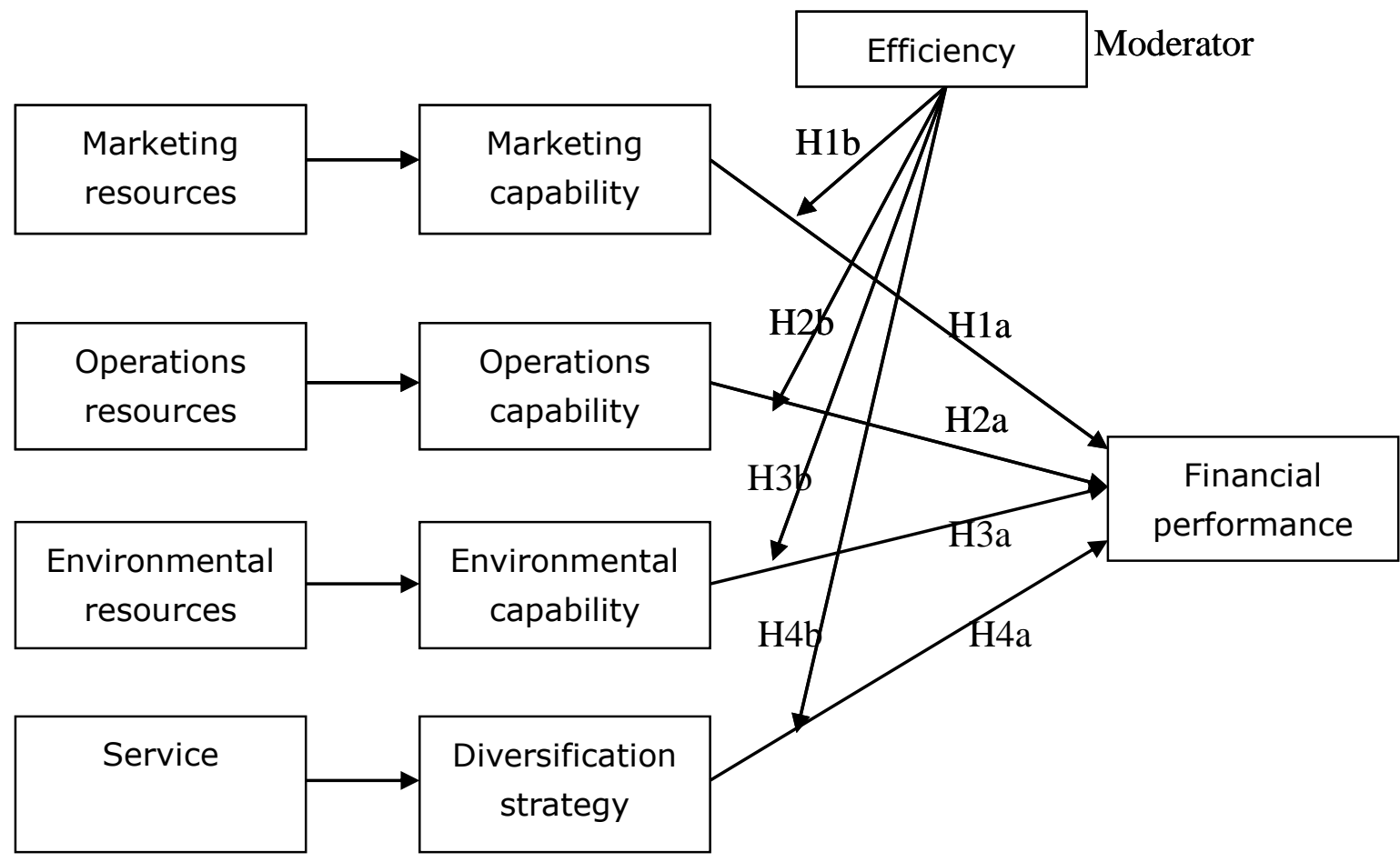

\subsubsection{Operations Capability}

A firm can obtain competitive advantage by using its operations capabilities (such as material flow process, utilization of asset, and related professional knowledge) efficiently, (Tan et al., 2007). An improved operations capability helps a firm to improve its output by using its production capabilities, technology, and flow of materials (Hayes et al., 1988) without adversely 
affecting cost of operations. Thus a firm with superior operations capability can increase its efficiency and gain competitive advantage (Day, 1994).

Efficient operations management can help hotels improve service quality and performance. Krasnikov and Jayachandran (2008) have found that operations capability, along with marketing and research and development (R\&D) capabilities, impact on a company's performance positively. Feng et al. (2009) have investigated the relationships between resource capabilities and performance and have found that operations resources and capabilities had positive impact on a company's performance. Therefore, we hypothesize that:

$H_{\text {la: }}$ Operations capabilities have positive impact on hotel financial performance.

Operations capabilities might have a significant impact on corporation's performance because of different rates of adaptation of capabilities (Krasnikov and Jayachandran, 2008). Some previous studies support that operations capabilities have varied influence on financial performance depending on other characteristics of firms such as efficiency (Vickery et al., 1993; Ortega and Villaverde, 2008; Song et al., 2007; Song et al., 2005). The hotels with proactive operations have better performance than those with conservative operations. The financial performance is better for hotels with more innovative and proactive operations capabilities (Jogaratnam and Tse, 2004). Operations capabilities can influence on firms at different levels, according to the various relationships between companies and business environments (McDaniel and Kolari, 1987; Song et al., 2005; Wu et al., 2006).

Based on the above arguments, we posit that hotels with efficient financial performance rely more on operations capabilities, since efficient hotels can use the limited capabilities more effectively. Thus, the hypothesis is as follows. 
$H_{1 b}$ : Operations capabilities have stronger positive impact on financial performance for efficient hotels.

\subsubsection{Marketing Capability}

Marketing capability is the integrative process of using intangible and tangible resources to satisfy demands of customers, to differentiate products and services, and to create brand competitive advantage (Day, 1994; Dutta et al., 1999; Song et al., 2007; Song et al., 2005). The RBV is generally drawn here; when a firm can integrate employees' skills and knowledge with its resource, it can expand its marketing capability (Vorhies and Morgan, 2005) that cannot be imitated by others to gain competitive advantage (Day, 1994).

There are previous studies that proved significant positive relationships between marketing capabilities and financial performance in the context of the US (Kumar et al., 1998). Marketing capability can accelerate a firm's good communication relationship with customers and create a strong brand for the firm, which leads to superior performance (Ortega and Villaverde, 2008). Additionally, a positive association between corporate reputation and firm's image will reflect in company's superior performance (Fryxell and Wang, 1994). However, some studies reveal there is no relationship between marketing and firm's performance (Sargeant and Mohamad, 1999).

In this paper we tentatively posit that the relationship between marketing capability and hotel performance is positive.

$H_{2 a}:$ Marketing capabilities have positive impact on hotel financial performance.

Marketing capabilities have different levels of impact on various firms depending on specific situations (Ortega and Villaverde, 2008; Song et al., 2005; 2007). For example, marketing 
capabilities have positive moderating effect on a firm's financial performance depending on its market orientation, marketing strategies, specific environment and several other moderating influences (Song et al., 2007).

In a dynamic business environment, the marketing capability plays different levels of roles based on the firm's relationship with its business environment (Ortega and Villaverde, 2008; Song et al., 2007). Firms with superior marketing capabilities perform much better (Kumar et al., 1998; Narver and Slater, 1990). It is easy to obtain competitive advantage for firms with fresh valueadding marketing strategies (Barney, 1991; Wernerfelt, 1984). According to Nath et al. (2010), marketing capabilities impact financial performance more positively for efficient firms.

These arguments help us to propose the following hypothesis:

$H_{2 b}$ : Marketing capabilities have stronger positive impact on financial performance for efficient hotels.

\subsubsection{Environmental Capability}

Modern organizations show higher levels of corporate social responsibility and generally aim to reduce environmental aspects arising from their business (Jimenez and Lorente, 2001). Hotels may not generate significant amounts of pollution compared to manufacturing, but the combined environmental impact of operations of several hotels could be significant (Kirk, 1995).

A hotel's environmental capability is influenced by several stakeholders, including shareholders and consumers. Studies have shown that environmental performance of firms is generally positively related to performance (Judge and Douglas, 1998). Potential advantages of inclusion of environmental issues in corporate strategy are suggested in the literature. Successful firms can use their slack resources to improve their environmental practices; on the other side, 
environmental practices can bring benefits to organizational performance (Alvarez-Gil et al., 2001). Environmental protection activities of a firm can influence its overall performance (Angell and Klassen, 1999). Some functional areas like marketing gain a competitive advantage based on environmental issues (Coddington, 1993).

Some studies have found an existence of a positive relationship between proactive environmental strategies and company's performance (Judge and Douglas, 1998; Klassen and McLaughlin, 1996). Some investigations (Molina-Azonrinet al., 2009) have pointed out that environmental practices can help hotels save costs and improve utilization of resources such as water and energy (Chan, 2005), and also influence customers' evaluation of a hotel's service quality, especially when the customers are environmentally sensitive (WTO, 1998).

Montabon et al. (2007), using content analysis and canonical correlation, have demonstrated significant and positive relationships between environmental management practices and performance. Molina-Azonrin et al. (2009) have investigated the impact of environmental practices on firm performance in Spanish hotel industry. Based on these studies, our next hypothesis is:

\section{$H_{3 a}:$ Environmental capabilities have positive impact on hotel financial performance.}

Previous studies have found that the impact of environmental performance on business could vary based on some other characteristics of hotels (Carmona-Moreno et al., 2004). Such factors include stakeholder pressures and organization size. In hotel industry, the environmental strategy is also related to the chain affiliation (IHEI, 1993). Molina-Azonrin et al. (2009) find that hotels can have a superior performance if they have a stronger commitment to environmental practices. However, there has been no research that investigated firms' efficiency could affect the 
influence of environmental capabilities on performance. We focus on this issue here. Drawing on previous related studies discussed above, we set the following hypothesis:

$H_{3 b:}$ Environmental capabilities have stronger positive impact on financial performance of efficient hotels.

\subsubsection{Diversification Strategy}

Service diversification exists in different forms. For instance, some hotels offer related services including catering, bars, restaurants, and so on. Such diversification can have mixed impacts on financial performance (Bettis and Mahajan, 1985). The companies can use current resources to expand their activities efficiently so as to help the firm to grow (Chatterjee and Wernerfelt, 1991). This observation is generally supported by the RBV theory (Theuvsen, 2004).

Diversification can create competitive advantages for firms by helping firms to seek value adding new services, by reducing business risks, by improving brand image, by helping to achieve economies of scale, and by helping them to leverage their experience in various markets (Rumelt, 1974). Such diversification generally has a positive impact on financial performance (Bettis, 1981; Chatterjee and Wernerfelt, 1991). However, some studies have suggested that diversification can have a negative impact on performance (Chakrabarti et al., 2007). Theuvsen (2004) has proved that diversification can increase operation expenditure, managerial and organizational complexity, and limit a firm's ability to quickly react to external changes.

Thus, as per the extant literature, the relationship between service diversification and financial performance can be both positive and negative (Geringer et al., 2000; Narasimhan and Kim, 2002). However, we tentatively posit a positive influence for hotels in the form of the following hypothesis. 


\section{$H_{4 a:}$ Service diversification strategies have positive impact on hotel financial} performance.

A firm can be recognized as a source of various "distributed knowledge". Successful transformation of knowledge between parent organization and subsidiaries can lead to the successful resource-capabilities-performance transformation. Companies with superior resources could leverage diversification to register superior financial performance (Chatterjee and Wernerfelt, 1991). Companies that are capable of transferring resources, such as knowledge and technology, more efficiently have registered better improvement in performance due to diversification (Fang et al., 2007). Using these observations, the following hypothesis is proposed. $H_{4 b}:$ Service diversification strategies have stronger positive impact on financial performance for efficient hotels.

\section{Research Methods, data and measurements}

\subsection{Research Methods}

To explore the individual impact of various capabilities and diversification strategy mentioned above, three main research methods - data envelopment analysis (DEA), content analysis, and regression have been used in this study. We have first developed measures, based only on secondary data, to estimate (1) operations capability, (2) marketing capability, (3) environmental capability, (4) diversification, and (5) firm efficiency. Measures for all but environmental capability have been obtained from archival financial data. Ours is the first study to discuss environmental capabilities in the conceptual framework shown by Figure 1. Presently there is no standard reporting procedure for environmental performance; hence we could not use archival financial databases to obtain measures for environmental capability, and we had to rely on content analysis of annual reports/ corporate social responsibility reports/ websites of hotels to 
develop scales and measure environmental performance. We have then used DEA to aggregate the measures into scores that capture the relative values of operations capability, marketing capability, environmental capability, diversification and firm efficiency for each hotel. We have then used ordinary regressions to investigate the impact of capabilities on performance. In order to understand the moderating effect of firm efficiency on the impacts, we have categorized hotels into two groups - efficient and inefficient - based on firm efficiency, and investigate the impacts on the two groups.

\subsection{Data}

We have chosen the hotel industry in the UK to test the framework. These hotel companies have primary UK SIC code of 5510 and provide hotel services and hotel related services. We have used the data mainly from the Financial Analysis Made Easy (FAME) data base for the year 2007 to test our hypotheses. Initially, we have selected top 500 hotels companies according to their turnover for our analysis. However, various analysis considerations have limited our sample size. A large number of companies do not list their intangible assets in the FAME database, which is an important data for analyzing the marketing capability. Since DEA cannot use negative data, we had to remove some hotels that had negative data (e.g., for working capital). Thus our final sample size reduced to 102 . Our sample size is generally considered adequate for a regression based statistical study. Several regression based studies published in the literature have used sample sizes similar to that used in our study (e.g., Roh et al. (2012) used 105 responses and Wang et al. (2010) used 133 responses) or lower (e.g., Wu et al., 2010 used a sample of 43 triads for testing their 
hypotheses using regression and Anand et al. (2010) used a sample size of 76. Ciurana et al., (2008) used 32 samples for multiple regression cost model.

As mentioned earlier, data of environmental capabilities are not available in FAME and hence we collected the relevant data using content analysis. Annual reports and corporate social responsibility reports (if any) of the hotels for the year 2007 have been used for content analysis (Holcomb et al., 2007). Hotel websites have also been used whenever needed.

\subsection{Choice of measures}

We have used several measures in this study to generate our constructs of interest (the three capabilities and diversification). We have used an input-output framework to measure these capabilities, and used the data envelopment analysis (DEA) to arrive at scores for the capabilities (Paradi et al.,2011; Demirbag, 2010). When DEA is used, firms are viewed as entities that convert some inputs (such as labour, capital, etc.) to useful outputs (such as profit). Thus, to measure capabilities, some measures as inputs and outputs need to be specified. In the next sub-sections, these input and output measures to arrive at scores for the different capabilities are discussed.

In line with previous studies (e.g., Nath et al., 2010), we have used an input oriented constant return to scale (CRS) DEA model to measure all the capabilities. An input oriented DEA model will help to determine whether a firm can produce the same level of output with less input (Barros and Athanasiou,, 2004; Yoshida and Fujimoto, 2004) and hence is useful to measure capabilities. A constant returns to scale model is used when there is no further information to make specific scale assumptions (Yoshida and Fujimoto, 2004). Some previous researches have also 
used DEA for measuring operational performance of vendors and supply chains (Xu et al., 2009; Talluri et al., 2006)

\subsubsection{Measuring Operations Capability}

Operations capabilities are important in hotels. Hotels' operations affect its services on the aspects of cost, quality and time delivery (Alvarez-Gil et al., 2001). Thus a hotel with better operations capabilities will be able to provide better customer service with minimum cost without affecting quality.

Basing arguments stemming from the RBV, several authors have employed measures such as efficiency in delivery process, technology development capabilities, cost of capital, cost of labor, cost of operations, and new service development capabilities to measure operations capabilities (Song et al., 2005; Song et al., 2007;). Based on these previous studies, we measure operations capability in this paper using two inputs (cost of capital and cost of labor) and one output (cost of operations). Cost of operations refers to the cost which the company uses to produce, create and transfer the product or service to customers. Hotels use various capital items, including rooms, furniture, telephones, televisions, kitchens, and cleaning machines, to create and provide services to clients. We use tangible assets as a measure of these capital items. Furthermore, cost of labor, as an input, refers to the expenditure on staff in hotels. The remuneration value can represent this expenditure; hence, it is regarded as the measure for this input.

As mentioned earlier, an input oriented constant return to scale (CRS) DEA model (Cooper et al., 2006) is used to measure the operations capability. In line with previous studies, the resulting 
DEA scores are then transformed to measure relative operations capability, computed by dividing the DEA score with the average DEA score of all hotels considered in a particular analysis.

\subsubsection{Measuring Marketing Capability}

Marketing literature has widely used primary data from surveys, such as advertisement effectiveness, customer service capability, and image differentiation (Song et al., 2007) to study marketing capability. There are comparatively fewer studies using secondary archival data to investigate the marketing capability (Dutta et al., 1999; Narasimhan et al., 2006). In this paper we have used archival financial data to measure marketing capability. Based on previous studies (Nath et al., 2010), turnover has been used in this study as the output to measure marketing capability. Marketing activities such as promotion, advertising, communication with customers and all kinds of marketing campaign, can be used to increase this output.

Four inputs have been used as input measures. They are stock of marketing expenditure, intangible resource, relationship, expenditure and installed customer base (Nath et al., 2010). Firstly, the administrative expenditure made by a company to achieve all marketing activities is considered as marketing expenditure (Narasimhan et al., 2006; Dutta et al., 1999). Secondly, the intangible resource is a representative of companies' success of building the brand reputation (Slotegraff et al., 2003). We have used the intangible assets mentioned in annual reports to measure the intangible resources. Thirdly, the relationship expenditures can be measured by cost of receivables. This is a proxy for the "customers' relationship effort" which is made by the companies (Dutta et al., 1999) and it is used by firm to setup and keep the relationship with customers. Hotels can use the relationship expenditure to provide trade incentives and build 
customer relationships. Fourthly, the installed customer base is described by Dutta et al. (1999) as stock of sales from earlier customers, and is normally measured by growth in sales revenue (Vorhies and Morgan, 2005). The customers' repetitive consumption in the hotels can create value for hotels distinctly.

As discussed for the case of operations capability, we have first used DEA to arrive at DEA scores of marketing capability, and then have computed the relative marketing capability of a hotel by dividing DEA scores of the hotel by average of DEA scores of all firms considered in the analysis.

\subsubsection{Measuring Environmental Capability}

Superior environmental capabilities result in improved environmental performance, leading to minimal negative impact on natural environment (Jimenez and Lorente, 2001). Pollution prevention can help companies to save costs, input and energy consumption, and reuse certain materials (Hart, 1995). Environmental performance of firms, in terms of efficient management of energy, water, waste, etc., has been a topic of several research studies (Alvarez-Gil et al., 2001; Carmona-Moreno et al., 2004; Holcomb et al., 2007; Kirk, 1995; Molina-Azorin, et al., 2009; Montabon et al., 2007). Environmental performance is not yet integrated well in annual financial reports, and hence data on environmental performance of companies are not readily available. Previous studies have used a variety of means to gather data on environmental performance. Some studies have used critical incident methodology (Valand and Heide, 2005), some have used event analysis derived from news reports (e.g., Klassen and McLaughlin, 1996), while some others have used content analysis to derive measures by reading annual reports, corporate social responsibility 
reports and company websites (e.g., Montabon et al., 2007). In this paper, we have used content analysis to gather data on environmental performance of hotels.

Content analysis is a research tool in the social sciences to systematically identify the presence of certain words or ideas from publicly available textual information (such as annual reports or web-sites). Our study uses content analysis of company corporate social responsibility reports available through websites of selected hotels to get useful information about their environmental performance and environmental awards. Since these reports are generally audited prior to being published, they provide reliable information. Content analysis thus provides the opportunity to collect data in an unobtrusive way without influencing the behaviour of the subjects (as in case studies or survey research) and converts the data into quantitative format for statistical analysis (Tangpong, 2011).

The authors of this study read annual reports, CSR reports and websites of hotels and rated specific environmental activities according to the following criteria:

1: The practice is not mentioned in the website/report.

3: Some information is given about the practice in the website/report.

5: More information is available for the practice in the website/report.

We have considered eleven environmental activities, one of which is considered as an output measure while the other ten are input measures (Figure 2). The output is the environmental award or recognition. Inputs include energy management (Carmona-Moreno, 2004), water management, waste management, carbon management, recycling, using ecological products (Alvarez-Gil et al., 2001), employees training on environmental awareness using ecological arguments in its marketing campaign (Alvarez-Gil et al., 2001; Molina-Azorin, 2009), integration with long term business strategy, and, facilitating customer collaboration in environmental 
protection (Carmona-Moreno, 2004). The hotels can encourage customers to participate in reducing energy and water consumption.

\section{Environmental} Resources

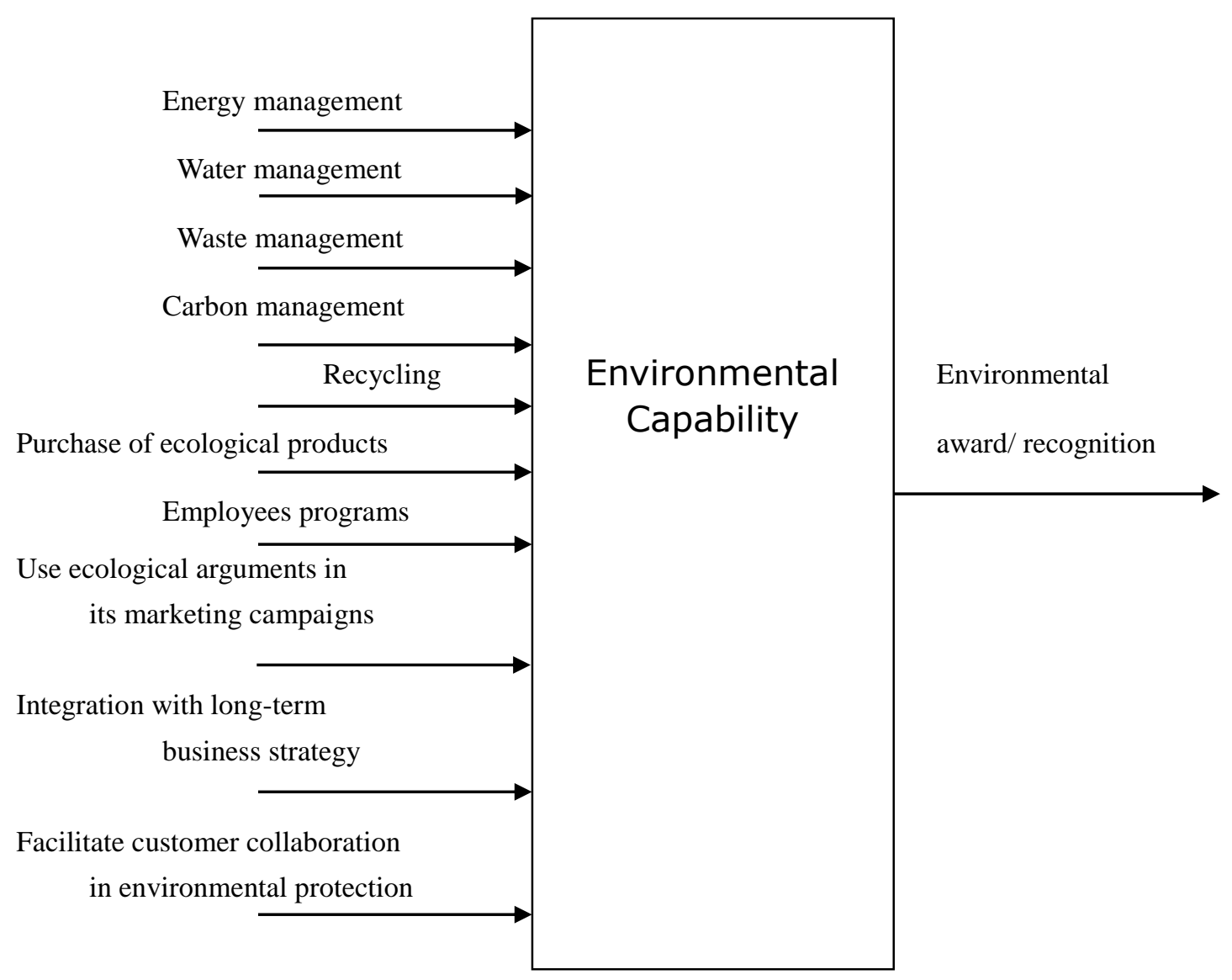

Figure 2 Framework to measure environmental capability

\subsubsection{Measuring Financial Performance}

Sales, profit margin, operating profit, return on investments have been considered in the literature as financial measures to study firm performance (Song et al., 2007; Song et al., 2005). Customer orientation, competitor orientation, customer satisfaction, market effectiveness have been used as non-financial measures to assess company performance (Vorhies and Morgan, 2005). In this paper, we have used operating profit as a measure of financial performance of hotels. There is a general consensus that operating profit can measure profitability of a firm (Song et al., 2007; 
Song et al., 2005), because it can illustrate the efficiency of firm's performance optimally, from the resource-output transformation perspective (Carmona-Moreno et al., 2004). Since this is a single measure of performance, we have not used DEA to get scores. However, we have divided the operating profit of a hotel by the average operating profit of all the firms to arrive at a relative measure of financial performance of the hotel.

\subsubsection{Measuring Diversification}

Diversification can be measured by entropy (Palepu, 1985), Herfindahl Index (Chakrabarti et al., 2007) or number of sectors operated by a firm (Nath et al., 2010). In this study the number of sectors of the hotels is used as the measure for evaluating the impact of diversification strategy on hotel's performance. Diversification can help a hotel perform better in some cases. For example, some hotels, such as the Intercontinental Hotels Ltd. also produce mineral waters and soft drinks. Some travel agencies such as Lastminute.com Ltd. operate hotels as well. Leeds cricket football and athletic company limited not only operates sports arenas but also hotels. However, diversification can also sometimes reduce the emphasis on core competence of hotels and can result in reduced business performance. Our study aims to test the impact of diversification using the hypotheses developed in Section 2.2.4. To test these hypotheses, we have obtained the information on the number of sectors operated by a hotel from the FAME database. Once the number of sectors operated by each hotel is available, the relative diversification of a hotel has been obtained by dividing the number of sectors of a hotel by the average number of sectors for all the hotels in the analysis. 


\subsubsection{Inputs and Outputs for Measuring Hotel Efficiency}

There are several studies that attempted to measure performance efficiency of hotels using DEA. Many previous researches in the hotel industry have used financial ratio measures (such as return on assets) to estimate efficiency. Neves and Lourenco (2005) have selected total assets and capital of hotels as inputs, and firms' revenue generating capacity as output. Nath et al. (2010) have chosen two inputs - total assets and working capital, and two outputs - return on assets and return on capital employed for measuring efficiency of logistics firms. Among the studies that used DEA for measuring efficiency of hotels, Barros (2005) has used labor, capital, operational costs and external costs as inputs, and sales, number of guests and the aggregated number of nights spent as outputs. Yu and Lee (2009) have used labor and some measures of capital (number of rooms, total floor area etc.) as inputs and some measure of sales (total revenue generated from rooms, total revenue generated from food \& beverages, and other revenue) as outputs. Based on these previous studies, we have chosen total assets (a measure of capital) as the input and return on assets and return on capital employed as outputs for measuring efficiency of hotels in this study.

Table 1 summarizes the inputs and outputs used to measure the three capabilities and efficiency of hotels in this study.

Table 1 Variables and measures

\begin{tabular}{lcc}
\hline & Variables & Measures (in G \\
\hline Operations capability (Feng et al., 2009; Krasnikov and Jayachandran, 2008; Nath et \\
Resources & Cost of capital & Tangible assets \\
& Cost of labor & Remuneration \\
Objectives & Cost of operations & Cost of sales
\end{tabular}

Marketing capability (Nath et al., 2010; Dutta et al., 1999; Narasimhan et al., 2006)

Resources Stock of marketing expenditure

Intangible resources

Relationship expenditure
Administrative expenses

Intangible assets

Cost of receivable 


$\begin{array}{lll} & \text { Installed customer base } & \text { Sales growth } \\ \text { Objectives } & \text { Sales } & \text { Turnover }\end{array}$

Enviromental capability (Molina-Azonrin et al., 2009; Montabon et al., 2007)

\begin{tabular}{|c|c|c|}
\hline Resources & Energy management & Content analysis coding \\
\hline & Water management & Content analysis coding \\
\hline & Waste management & Content analysis coding \\
\hline & Carbon management & Content analysis coding \\
\hline & Recycling & Content analysis coding \\
\hline & $\begin{array}{l}\text { Purchase of ecological products (Develop } \\
\text { green purchasing) }\end{array}$ & Content analysis coding \\
\hline & $\begin{array}{l}\text { Employees programs (Employees' education } \\
\text { and training on the aspect of environment) }\end{array}$ & Content analysis coding \\
\hline & $\begin{array}{l}\text { Use ecological arguments in its marketing } \\
\text { Campaigns }\end{array}$ & Content analysis coding \\
\hline & Integration with long-term business strategy & Content analysis coding \\
\hline & $\begin{array}{l}\text { Facilitate customer collaboration in } \\
\text { environmental protection (Voluntary changing } \\
\text { of towels, etc) }\end{array}$ & Content analysis coding \\
\hline Objectives & Environmental award/recognition & Content analysis coding \\
\hline
\end{tabular}

Diversification strategy (Geringer et al., 2000; Narasimhan and Kim, 2002)

Service

diversification
Financial

Sectoral concentration Number of sectors

performance

Profitability Operating profit

Efficiency (Nath et al., 2010; Barros, 2005; Yu and Lee, 2009)

$\begin{array}{lll}\text { Inputs } & \text { Assets } & \text { Total assets } \\ \text { Outputs } & \text { Return on assets } & \text { Actual value (\%) } \\ & \text { Return on capital employed } & \text { Actual value (\%) }\end{array}$

\section{Analysis and Results}

We have employed hierarchical linear regression to test our hypotheses. To test the direct effects of the capabilities on performance (i.e., hypotheses 1a, 2a, 3a and 4a), we estimate a regression equation with performance as dependent variable and operations capability, marketing capability, environmental capability and diversification as the independent variables. Hypotheses $1 b-4 b$ deal with the moderating effect of efficiency. To test these hypotheses, we first divided the entire set of hotels into two groups (efficient and inefficient), performed regression for both the groups, and assessed the moderating effects of efficiency by comparing the magnitude and 
significance of the independent variables. For the regressions discussed in this section, we first carried out the regular tests to check regression assumptions. These tests include those to check normality assumption of the error terms, multi-collinearity and heteroskedasticity. We have verified and found that all assumptions for regression are satisfied. There was no evidence of multicollinearity with all variable-inflation factors below the threshold of 5 (Hair et al., 2006).

We first present descriptive statistics of our data in Table 2. It includes the summary measures for all hotels, efficient group and inefficient group for 2007. It can be seen that standard deviation is relatively large for most of variables.

Table 2 Descriptive summary of measures

\begin{tabular}{|c|c|c|c|c|c|c|}
\hline \multirow[t]{2}{*}{2007} & \multirow{2}{*}{$\begin{array}{l}\text { Overall } \\
\text { Mean }\end{array}$} & \multirow{2}{*}{$\frac{(n=102)}{S D}$} & \multirow{2}{*}{$\frac{\text { Efficient }}{\text { Mean }}$} & \multirow{2}{*}{$\frac{(n=51)}{S D}$} & \multirow{2}{*}{$\frac{\text { Inefficient }}{\text { Mean }}$} & \multirow{2}{*}{$\frac{(n=51)}{S D}$} \\
\hline & & & & & & \\
\hline Marketing capability & 40.7325 & 27.0822 & 46.1743 & 27.8695 & 35.2908 & 25.3858 \\
\hline Operations capability & 14.8325 & 22.8618 & 19.1716 & 26.8456 & 10.4933 & 17.2243 \\
\hline Environmental capability & 70.3981 & 16.0815 & 79.0869 & 15.7547 & 60.9825 & 11.361 \\
\hline Diversification & 1.8922 & 1.2813 & 2.0196 & 1.42113 & 1.7647 & 1.12407 \\
\hline Financial performance & 12904 & 40103 & 3227.8 & 5893.19 & 22580 & 0.4067 \\
\hline Efficiency & 6.6211 & 16.8961 & 12.8355 & 22.3105 & 54981.2 & 0.3509 \\
\hline
\end{tabular}

SD represents the standard deviation. Marketing capability, Operations capability, Environmental capability and Efficiency are relative DEA scores, measured in percentages. Diversification is measured by the number of service sectors in a hotel. Financial performance is measured by operating profit (in thousand $f$ ).

\subsection{Testing Direct Effects - Hypotheses 1a - 4a}

Our sample size was 102. Regression results for testing direct effects are presented in Table

3.

Table 3 Regression results for testing direct effects

\begin{tabular}{|c|c|}
\hline & Unstandardardized Coefficients \\
\hline \multicolumn{2}{|c|}{ Main effect } \\
\hline Overall & $(n=102)$ \\
\hline
\end{tabular}




\begin{tabular}{|l|l|}
\hline (Constant) & -0.386 \\
\hline Operations capability & $.737 * * *$ \\
\hline Marketing capability & $-.378 * *$ \\
\hline Environmental capability & $1.203 * * *$ \\
\hline Service diversification & -0.112 \\
\hline Fit statistics & 0.776 \\
\hline R Square & 0.767 \\
\hline Adjusted R Square & $84.082 * * *$ \\
\hline F-value & $* * * p<0.001 * * p<0.05 * p<0.1$ \\
\hline
\end{tabular}

It can be seen from Table 3 that the adjusted $\mathrm{R}^{2}$ is 0.767 is fairly high. In addition, F-value is significant highlighting that the overall regression is acceptable. All the three capabilities (operations, marketing and environment) are significant in explaining performance of hotels. While operations and environmental capabilities have positive coefficients, marketing capability seems to affect performance of hotels negatively. Service diversification has no significant impact on hotel performance. Therefore, Hypothesis la (operations capability has positive impact on hotel's financial performance) and Hypothesis $3 a$ (environmental capabilities have positive impact on hotel's financial performance) are supported, but Hypothesis 2 a (marketing capability has positive impact on the hotel financial performance) and Hypothesis 4 a (service diversification has a positive impact on a hotel's financial performance) are not supported.

\subsection{Testing the moderating effects - Hypotheses $1 b-4 b$}

As mentioned earlier, we have tested the moderating effects of efficiency by dividing the set of hotels into two groups - efficient and inefficient. In order to ensure approximately equal sample size for the two groups, we have used median split: the top 50\% hotels in terms of 
efficiency are considered as the efficient group, and the other $50 \%$ hotels are regarded as the inefficient group.

Regression results for the two groups are shown in Table 4. For efficient hotels, the table shows that adjusted $\mathrm{R}^{2}$ is high at 0.901 . The overall regression, based on the F-value, is significant. The relationship between operations capability and performance is significantly positive $(\beta=0.826$, $\mathrm{p}<0.001)$. There is a significantly negative association $(\beta=-0.245, \mathrm{p}<0.05)$ between marketing capability and hotel performance. In addition, the environmental capability has a significantly positive impact on performance $(\beta=0.643, \mathrm{p}<0.05)$. Service diversification does not influence performance significantly.

Table 4 Regression results for testing the moderating effect of efficiency

\begin{tabular}{|l|c|c|}
\hline \multicolumn{1}{|c|}{ Unstandardardized Coefficients } & Efficient group $(\mathrm{n}=51)$ & Inefficient group $(\mathrm{n}=51)$ \\
\hline (Constant) & -0.342 & -0.289 \\
\hline Operations capability & $.826^{* * *}$ & $.877 * * *$ \\
\hline Marketing capability & $-.245^{*}$ & $-.459^{*}$ \\
\hline Environmental capability & $.643^{* *}$ & $1.350^{* * *}$ \\
\hline Service diversification & -0.068 & -0.196 \\
\hline R Square & 0.909 & 0.684 \\
\hline Adjusted R Square & 0.901 & 0.657 \\
\hline F-value & $114.251^{* * *}$ & $24.933 * * *$ \\
\hline
\end{tabular}

$* * * p<0.001 \quad * * p<0.05 \quad * p<0.1$

The results shown in the last column of Table 4 shows that the regression for the inefficient group has a good adjusted $\mathrm{R}^{2}$ of 0.657 . The $F$ - value, indicating the overall credibility of the regression, is also significant. Significant of the three capabilities and diversification are almost similar to that of efficient group; the only difference is that environmental capability is more 
significant for inefficient group $(\mathrm{p}<0.001)$ that for efficient group $(\mathrm{p}<0.05)$. In addition, the magnitude of marketing capability and environmental capability are different for the two groups.

Since the significance of the three capabilities and diversification are similar for both efficient and inefficient groups, the moderating role of efficiency is not supported. Thus H1b, H2b, $\mathrm{H} 3 \mathrm{~b}$ and $\mathrm{H} 4 \mathrm{~b}$ are not supported in our analysis. It may be noted that while the magnitude of the coefficient of operations capability is almost similar for both efficiency and inefficient groups, the magnitudes of marketing capability and environmental capability are different in both the groups. Marketing capability has more negative impact and environmental capability has more positive impact on performance for inefficient hotels than for efficient hotels.

\section{Discussion}

This study has explored the impacts of marketing capability, operations capability, environmental capability and diversification strategy on the performance of hotel industry in the UK. In the following sections, we highlight some theoretical, practical and managerial implications of our findings.

\subsection{Operations capability}

Our results show that operations capability is highly significant in influencing performance of hotels in the UK. This emphasizes the importance of operations management in the hotel management process, and it is consistent with majority of existing literature (Klassen and McLaughlin, 1996; Krasnikov and Jayachandran, 2008). The operations capability is related to the hotels' long term operation strategy. Therefore, achieving the superior performance on hotel's operation capability can lead to the superior financial performance for a long period. This result is consistent with the operational extant literature (Hsu et al., 2009; Tan et al., 2007). However, 
operations capability is highly significant for both efficient and inefficient hotels, indicating the absence of any moderating effect of efficiency on the relationship between operations capability and performance. Moreover, the magnitude of the coefficients ( 0.826 for efficient group and 0.877 for inefficient group) are approximately equal, supporting the absence of the moderating impact. Thus, both efficient and inefficient hotels seem to perform well in terms of operations capability. In this context, results of our study are somewhat different from those of McDaniel and Kolari (1987), Song et al. (2005) and Wu et al. (2006).

It may be noted that the magnitude of coefficient of marketing capability is more negative when the corresponding coefficient of operations capability is more positive (in the case of inefficient groups). This highlights the complementary roles of these two capabilities in the UK hotels. Inefficient hotels with more negative performance in terms of marketing attempt to improve their performance by relying more on operations performance. This observation is consistent with the findings of Moorman and Slotegraaf (1999), who have suggested that the performance can be enhanced by complementary capabilities. It also means that the two capabilities can be integrated to an overall financial performance.

\subsection{Marketing capability}

As per the result shown in Table 3 , marketing capability is significant $(\mathrm{p}<0.05)$ but negative in influencing performance of hotels in the UK. Since the sign of the coefficient of marketing capability is negative, implying that hotels with higher marketing capability tend to perform less well. This finding has been generally supported by previous hotel literature in the UK (Greenly, 1995; Sargeant and Mohamad, 1999). 
Hypothesis $2 b$ is not supported; the significance of marketing capability does not vary based efficiency of hotel performance. This is different from the research result of Nath et al. (2010). However, the magnitude of the coefficient of marketing capability is more negative (0.459) for inefficient hotels than for efficient hotels (-0.245). In contrast, as highlighted previously, operations capability seems to have a higher level of positive impact on performance when marketing capability has a higher level of negative impact. Thus, inefficient companies, tend to rely more on operational performance than on marketing performance. This finding is consistent with that of Nath et al. (2010).

\subsection{Environmental capability}

As mentioned earlier, the inclusion of environmental capability on hotel performance is relatively new and is a contribution of this paper. Hence, there are not many previous studies that could be compared in the hotel literature. Our study shows that environmental capability has a positive significant impact on hotel performance. This result generally agrees with findings in the extant literature (Carmona-Moreno et al., 2004; Molina-Azorin et al., 2009).

Efficient environment management needs special investments, such as buying the ecological products at a higher price, installing the environmental protection facilities, innovation, and training employees, but the high cost can be offset by higher saving in other aspects, like lower energy consumption, water saving and efficient utilization of inputs. The environmental management is usually a long term strategy. Especially the proactive practices, such as pollution prevention activities, can bring a variety of benefits to hotels, including saving cost, providing differentiation service, improve service quality, build environmental reputation, strength brand 
competitive advantage and create intangible assets. Thus, the environmental capability can create the superior financial performance for hotels.

Table 4 shows that environmental capability is equally significant for both efficient and inefficient hotels, highlighting the absence of any moderating role of efficiency on the impact of environmental capability on hotel performance. However, the magnitude of the coefficient of environmental capability is quite high (1.350) for inefficient group than for efficient group (0.643). Thus, there is evidence that inefficient hotels tend to perform well in terms of environmental capability. We have made a similar observation during our discussion on operations capability. Thus, based on our results, there is an indication that hotels that perform well in terms of operations capability also perform well in terms of environmental capability. This might be due to the close association between operations and environmental performance, which has been sufficiently highlighted in the literature. Operations capabilities are important in a firm's ability to undertake waste minimization efforts in particular and in developing environment friendly activities in general (Doh et al., 2010). Thus that firms that are proactive in improving their operations efficiency and invest in lean programs would perform better in terms of environmental sustainability initiatives as well. The results of Table 4 support this view.

\subsection{Service diversification}

The results in this study show that service diversification does not have relationship with hotel financial performance. This finding is generally consistent with diversification literature. It is suggested that not all the companies can improve the performance by diversification (Chakrabarti et al., 2007). Diversification strategy does not have impact on hotel corporate 
financial performance, but can partly promote the stability of performance (Lee and Jang, 2007). Diversification strategy of business helps companies to expand the service portfolio, and the overall risk of operation can be decreased for this strategy (Amit and Schoemaker, 1993), but diversification need not bring extra financial profit to the companies.

Our results point to the absence of any moderating effect of efficiency in the hotel industry in the UK. This has been proved in the previous study (Nath et al., 2010) for logistics industry.

\subsection{Theoretical implications}

We believe that our results support the RBV as a theoretical paradigm. This theory supports the use of a firm's resources and capabilities to achieve sustained competitive advantage. Our results confirm the tenets of this theory because all the three capabilities (operations, marketing and environmental) have significant influence on performance. This finding goes on to prove the arguments in the RBV literature that firm that undertake conscious and systemic efforts in improving its production and service delivery processes accumulate a set of wealthy knowledge and translate into internal competitive advantages, which cannot be imitated by competitors (Russo \& Fouts, 1997; Kraaijenbrink et al., 2010). However, marketing capabilities seem to have negative impact, contrary to popular opinion. This finding may highlight the narrow view that this capability alone will not help a firm to achieve competitive advantage. RBV is further supported in that the significant capability-performance relationships are not affected by the efficiency levels of firms. Our results support the strategic need for harnessing internal resources to meet external demands (Collis and Montgomery, 1995). 
Two proponents of RBV have identified key specific organizational resources that would link capabilities (specifically environmental capabilities) with financial performance in firms: Hart (1995) has argued for continuous improvement and stakeholder management, while Russo and Fouts (1997) extended this set to include the deployment of physical assets and technology, organizational culture, interfunctional coordination, and intangible resources. We believe that our findings generally support these arguments. Continuous improvement, physical assets and technology, and, improved coordination result in improvement of operational capabilities while stakeholder management improves marketing capabilities. In summary, we believe that our study highlights the greater breadth of the applicability of the RBV to understand the role of resourcecapabilities in giving competitive edge to firms.

\subsection{Managerial implications}

The results reveal significant managerial implications for the hotel industry business. Our results have shown that operations capability has a significant positive impact on hotel performance. It proves that hotels investing more resources on building operations capability can lead to a really superior financial performance. Thus, hotels should consider operations capability as the main investment, such as hotel facilities, lean performance, etc., to get a constant superior performance during a long time. Efficiency is not a moderator in affecting the impact of operations capability on performance; operations capability is significant for both efficient and inefficient groups. However, the impact of operations capability is more positive for inefficient groups, indicating that the impact of operations capability is stronger for inefficient hotels. 
Marketing capability significantly impacts hotel performance but in reverse direction. Thus hotels with superior marketing capability generally register less superior performance. This could imply that hotels in the UK may be more active in their marketing efforts than necessary. Since operations capability has a positive impact on performance, our findings suggest for the need for a balanced focus on marketing and operations capabilities. Marketing can be planned as a longterm investment for hotels.

Environmental capability significantly positively affects hotel performance but there is no moderating impact of efficiency on this link. Thus firms that spend efforts on improving their environmental performance register superior corporate performance. Our results also highlight the close connections between environmental capability and operations capability, which has already been sufficiently stressed in the literature. Thus, hotels can invest in waste minimization, recycling, energy conservation, etc. also perform well in terms of their operations capability, and the combined effect will be reflected on superior corporate performance. Therefore, enhancing the environmental management is one of the key elements leading to successful performance. Both efficient and inefficient hotels ought to allocate more resources on environmental capability. Good environmental performance can attract more customers to hotels, especially the environmental sensitive clients, and build a reputation for providing services which protect natural environment. If a hotel provides environmental capability on a vital management status, this will lead to the superior financial performance.

The results of service diversification strategy show no relationship between diversification and hotel performance. It implies that hotels can consider service diversification as a developing strategy, but it need not be an indispensable one. Hotels need to choose between diversifying in 
several sectors or focusing on a single core sector based on their own characteristics and competence.

\section{Conclusions, Limitation and Directions for Future Research}

This paper has explored relationships between resources, capabilities, environment, diversification and performance. We have developed hypotheses linking operations capability, marketing capability, environmental capability and service diversification with financial performance. We have tested these relationships using archival data on hotels in the UK, and have found that the three capabilities have significant relationship with hotel performance. In addition, we have explored the moderating effect of efficiency on these relationships but found that efficiency has not moderated these relationships.

While we have argued, using the resource based view, the existence of significant positive impacts of the three capabilities on financial performance and found supporting evidence in the context of UK hotels in our study, we would also like to highlight that some previous studies did not find support for these positive relationships. Though we have discussed several studies that found positive relationship between marketing capabilities and performance, Bull (2003) and Corner and Hinton (2002) have found that marketing capability such as customer relationship management was not positively associated with firm performance in some cases, while Chang et al. (2010) have found that this relationship may be more complex involving issues such as mediation. Similarly, though several studies discussed earlier highlighted positive relationships between environmental capabilities and firm performance, other such as Hitchens et al (2005) and Margolis and Walsh (2003) have not found such significant relationships, while Vogel (2005) argued for more complex relationships. Similar arguments can also be found on the relationship between operations capabilities and performance (e.g., Hsu et al., 2009). In spite of these studies 
arguing for non-existence or existence of complex relationships, our study highlights that there is evidence for direct and positive relationships between the three capabilities and financial performance.

This study contributes to the investigation of hotel industry in the UK in several ways. This is one of the few studies that have measured the three capabilities using a framework based on data envelopment analysis, and comprehensively addressed the links between the capabilities and financial performance. More importantly, this is the first study to investigate the above relationships in the hotel literature. In addition, this study is the first to consider environmental capability in the DEA based input-output framework.

Though our data and analysis focused on the hotel industry, we believe that our findings can be generalized to broader contexts, for example to the services sector in general. For most of the services sector, marketing and operations capabilities contribute significantly to performance (e.g., Ortega and Villaverde, 2008 for ICT sector, Yu et al. (2014) for retail, and Wu et al., 2006 for logistics). Our findings support these previous results for the general services sector with objective, secondary data from the UK hotel industry. However, the link between environmental capabilities and firm performance has not been tested exclusively for the services sector though there are several studies in the general context (e.g., Montabon et al., 2007). Our study is perhaps one of the first studies testing this link in hotel context.

This study has some limitations that can be addressed in future research studies. (i) To our knowledge, this is the first study that has integrated environmental capability with other capabilities and study impacts on performance. As we highlighted in Section 3.3.3, environmental performance is not yet integrated in financial reports, making it hard to collect data on 
environmental capability. We have used previous studies (Molina-Azonrin et al., 2009; Montabon et al., 2007) to help in the measurement of environmental capability and attempted to cover as many indicators as possible (shown in Table 1). Though we have measured environmental capability using 11 indicators (10 inputs and one output), we may not have captured all possible measures. This certainly provides scope for future work. (ii) Some of our findings could be different if we performed the analysis for different star ratings of hotels. For example, high levels of diversification could be more beneficial to hotels with higher star ratings than to hotels with lower star ratings. Thus an analysis for groups of hotels with different star ratings could be an interesting work for future research. (iii) Some of the indicators used to measure capabilities could be improved. For example, word-or-mouth could play a very important role in improving marketing capability but it cannot be measured using secondary sources. Since this paper is concerned with using only secondary data (in line with the focus of this special issue), we have not included word-of-mouth in the measurement of marketing capability in this paper. However, a more rigorous analysis is possible when primary data is collected using specially designed surveys or interviews. This will also help in using more direct measures of different capabilities such as the quality of service. (iv) Though our study has considered more capabilities compared to previous studies, more relevant factors, such as the impact of location on hotel performance, can also be focused in future studies. (v) It would be interesting to extend the framework of this study to other sectors, and check if the same findings can be generalized over a number of industrial sectors. (vi) Finally, the relationships over a period of time can be analyzed using time series data as such data can be obtained from historical annual reports.

\section{References}


Alvarez-Gil, M. J., Burgos-Jimenez, J., \& Cespedes-Lerente, J. J. (2001). An analysis of environmental management, organizational context and performance of Spanish hotels. The International Journal of Management Science, 29, 457-471.

Amit, R., \& Schoemaker, P. J. (1993). Strategic assets and organizational rent. Strategic Management Journal, 14(1), 33-46.

Angell, L. C., \& Klassen, R. D. (1999). Integrating environmental issues into the mainstream: An agenda for research in operations management: An agenda for research in operations management. Journal of Operations Management, 17(5), 575-598.

Barney, J. B. (1991). Firm resources and sustained competitive advantage. Journal of Management, 17(1), 99-120.

Barney, J. B., \& Zajac, E. J. (1994). Competitive organizational behavior: Toward an organizationally-based theory of competitive advantage. Strategic Management Journal, $15,5-9$.

Barros, C.P., (2005). Measuring efficiency in the hotel sector, Annals of Tourism Research, 32 (2), 456-477.

Barros, C.P., Athanasiou, M. (2004). Efficiency in European seaports with DEA: evidence from Greece and Portugal. Journal of Maritime Economics and Logistics 6(2), 122-140.

Bettis, R. (1981). Performance difference in related and unrelated diversified firms. Strategic Management Journal, 2, 379-393.

Bettis, R. A., \& Mahajan, V. (1985). Risk/return performance of diversified firms. Management Science, 31(7), 785-799.

Bull C. (2003), Strategic issues in customer relationship management (CRM) implementation. Business Process Management Journal, 9(5),592-602.

Carmona-Moreno, E., Cespedes-Lorente, J., \& Burgos-Jimenez, J. D. (2004). Environmental strategies in Spanish hotels: Contextual factors and performance. The Service Industries Journal, 24(3), 101-130.

Chakrabarti, A., Singh, K., \& Mahmood, I. (2007). Diversification and performance: Evidence from East Asian firms. Strategic Management journal, 28(2), 101-120.

Chan, W. W. (2005). Partial analysis of the environmental costs generated by hotels in Hong Kong. Tourism Management, 24, 517-531.

Chang, W., Park, J. E. and Chaiy, S. (2010), How does CRM technology transform into organizational performance? A mediating role of marketing capability, Journal of Business Research, 63 (8), 849-855.

Chatterjee, S., \& Wernerfelt, B. (1991). The link between resources and type of diversification: Theory and evidence. Strategic Management Journal, 12(1), 33-48.

Ciurana, J., Quintana, G.,\& Garcia-Romeu, M.L. (2008). Estimating the cost of vertical high-speed machining centres, a comparison between multiple regression analysis and the neural networks approach. International Journal of Production Economics, 115 (1), 171178.

Coddington, W. (1993). Environmental Marketing: Positive Strategies for Reaching the Green Consumer. New York: McGraw Hill. 
Collis, D. and C. A. Montgomery (1995), Competing on Resources: Strategy in the 1990s, Harvard Business Review, 73 (July-August), pp.118-128.

Cooper, W. W., Seiford, L. M., \& Tone, K. (2006). Introduction to data envelopment analysis and its uses: with DEA solver. New York: Springer Science and Business Media Inc.

Corner I, Hinton M. (2002), Customer relationship management systems: implementation risks and relationship dynamics, Qualitative Marketing Research: An International Journal, 5(4), 239-51.

Day, G. S. (1994). The capabilities of market driven organizations. Journal of Marketing, 58, 37-51.

Demirbag, M., Tatoglu, E., Glaister, K. W. a\& Zaim, S. (2010). Measuring strategic decision making efficiency in different country contexts: A comparison of British and Turkish firms. Omega: The international Journal of Management Science, 38 (1-2), 95-104.

Doh, J. P., Howton, S. D., Howton, S. W., \& Siegel, D. S. (2010). Does the market respond to an endorsement of social responsibility? The role of institutions, information, and legitimacy. Journal of Management, 36(6), 1461-1485. Dutta, S., Narashiman, O., \& Surendra, R. (1999). Success in high technology markets: Is marketing capability critical? Marketing Science, 18(4), 547-568.

Dutta, S., Narashiman, O., \& Surendra, R. (1999). Success in high technology markets: Is marketing capability critical? Marketing Science, 18(4), 547-568.

Fang, Y., Wade, M., Delios, A., \& Beamish, P. W. (2007). International diversification, subsidiary performance, and the mobility of knowledge resources. Strategic Management Journal, 28, 1053-1064.

Feng, Y. Y., Pan, W. H., Huang, Y. H., \& Chen Y. K. (2009). The effect of firms resources and capabilities on its performance of IC design industry in Taiwan. Information Technology Journal, 8(5), 688-697.

Fryxell, G. E., \& Wang, J. (1994). The Fortune corporate "reputation" index: Reputation for what? Journal of Marketing, 20(1), 1-14.

Geringer, J. M., Tallman, S., \& Olsen, D. M. (2000). Product and international diversification among Japanese multinational firms. Strategic Management Journal, 21(1), 51-80.

Greenley, G. E., \& Foxal, G. R. (1997). Multiple stakeholder orientation in UK companies and the implications for company performance. Journal of Management Studies, 34, 259284.Hair, J.F., Black, W.C., Babin, B.J., Anderson, R.E., Tatham, R.L., 2006. Multivariate data analysis. $6^{\text {th }}$ edition Prentice-Hall, New Jersey.

Hart, S. L. (1995). A natural-resource-based view of the firm. Academy of Management Review, 20(4), 986-1014.

Hayes, R. H., Wheelwright, S. C., \& Clark, K. B. (1988). Dynamic manufacturing. New York: Free Press.

Hitchens, D., Thankappan, S., Trainor, M., Clausen, J., De Marchi, B. (2005),. Environmental performance, competitiveness and the management of small businesses in Europe, Tijdschrift voor Economische en Sociale Geografie, 96 (5), 541-557.

Holcomb, J. L., Upchurch, R. S., \& Okumus, F. (2007). Corporate social responsibility: What are top hotel companies reporting? International Journal of Contemporary Hospitality 
Management, 19(6), 461-175.

Hsu , C.-C., Tan , K. C., Kannan, V. R. \& Keong Leong, G. (2009): Supply chain management practices as a mediator of the relationship between operations capability and firm performance, International Journal of Production Research, 47(3), 835-855.

IHEI-International Hotels Environment Initiative (1993). Environmental management for hotels. Oxford: Butterworth-Heinemann.

Jimenez, J. B., \& Lorente, J. J. C. (2001). Environmental performance as an operations objective. International Journal of Operations \& Production Management, 21(12), 15531572.

Jogaratnam, G., \& Tse, E. C. (2004). The entrepreneurial approach to hotel operation. Cornell Hotel and Restaurant Administration Quarterly, 45(3), 248-259.

Judge, W. Q., \& Douglas, T. J. (1998). Performance implications of incorporating natural environmental issues into the strategic planning process: An empirical assessment. Journal of Management Studies, 35(2), 241-262.

Kirk, D. (1995). Environmental management in hotels. International Journal of Contemporary Hospitality Management, 7(6), 3-8.

Klassen, R. D., \& McLaughlin, C. P. (1996). The impact of environmental management on firm performance. Management Science, 42(8), 1199-1214.

Kraaijenbrink, J., Spender, J. C., \& Groen, A. J. (2010). The resource-based view: a review and assessment of its critiques. Journal of management, 36(1), 349-372.

Krasnikov, A. \& Jayachandran, S. (2008). The relative impact of marketing, research-anddevelopment, and operations capabilities on firm performance. Journal of Marekting, 72, $1-11$.

Kumar, K., Subramanian, R., \& Yauger, C. (1998). Examining the market orientationperformance relationship: A context-specific study. Journal of Management, 24(2), 201233.

Lee, M. J., \& Jang, S. C. (2007). Market diversification and financial performance and stability: A study of hotel companies. Hospitality Management, 26, 362-375.

Lei, D., Hitt, M. A., \& Bettis, R. (1996). Dynamic core competences through meta-learning and strategic context. Journal of Management, 22, 549-569.

Margolis, J.D., Walsh, J.P. (2003),. Misery loves companies: Rethinking social initiatives by business, Administrative Science Quarterly, 48; 268-305.

McDaniel, S. W., \& Kolari, J. W. (1987). Marketing strategy implications of the Miles and Snow strategy typology. Journal of Marketing, 51, 19-30.

Molina-Azonrin, J., Claver-Cortes, E., Pereira-Moliner, J., \& Tari, J. J. (2009). Environmental practices and firm performance: An empirical analysis in the Spanish hotel industry. Journal of Cleaner Production, 17, 516-524.

Montabon, F., Sroufe, R., \& Narasimhan, R. (2007). An examination of corporate reporting, environmental management practices and firm performance. Journal of Operations Management, 25, 998-1014.

Moorman, C., \& Slotegraaf, R. J. (1999). The contingency value of complementary capabilities 
in product development. Journal of Marketing Research, 36(5), 239-257.

Narasimhan, O., Rajiv, S., \& Dutta, S. (2006). Absorptive capacity in high technology markets: The competitive advantage of the haves. Marketing Science, 25(5), 510-524.

Narasimhan, R., \& Kim, S. W. (2002). Effects of supply chain integration on the relationship between diversification and performance: Evidence from Japanese and Korean firms. Journal of Operations Management, 20, 303-323.

Narver, J. C. \& Slater, S. F. (1990). The effect of a market orientation on business profitability. Journal of Marketing, 54(4), 20-35.

Nath, P., Nachiappan, S. and Ramanathan, R. (2010). The Impact of Marketing Capability, Operations Capability and Diversification Strategy on Performance for Logistics Service Providers: A Resource-Based View. Industrial Marketing Management, 39 (2), 317-329.

Neves, J. C., \& Lourenco, S. (2005). Designing a strategy to improve performance through a DEA model: The case of hotel industry. Paper presented at Conference at European Management Academy, Munich.

Ortega, M. J. R. \& Villaverde, P. M. G. (2008). Capabilities and competitive tactics influences on performance: Implications of the moment of entry. Journal of Business Research, 61, 332-345.

Palepu, K. (1985). Diversification strategy, profit performance, and the entropy measure. Strategic Management Journal, 6(3), 239-255.

Paradi, J. C., Rouatt, S., \& Zhu, H. (2011). Two-stage evaluation of bank branch efficiency using data envelopment analysis. Omega: The international Journal of Management Science, 39 (1), 99-109.

Ramanathan, R. (2010), The Moderating Roles of Risk and Efficiency on the Relationship between Logistics Performance and Customer Loyalty in E-Commerce, Transportation Research Part E: Logistics and Transportation Review, 46 (6), 950-962.

Ramanathan, U. \& Gunasekaran, A., (2014). Supply chain collaboration: Impact of success in long-term partnerships. International Journal of Production Economics. 147, 252-257

Rumelt, R. P. (1974). Strategy, structure and economic performance: Division of research. Boston: Harvard Business School.

Russo, MV, and Fouts PA. 1997. A resource-based perspective on corporate environmental performance and profitability. Academy of Management Journal, 40 (3): 534-559.

Sainaghi, R. (2010). Hotel performance: state of the art. International Journal of Contemporary Hospitality Management, 22(7), 920-952.

Sargeant, A., \& Mohamad, M. (1999). Business performance in the UK hotel sector-Does it pay to be market oriented? The Service Industries Journal, 19(3), 42-59.

Slotegraff, R. J., Moorman, C., \& Inman, J. J. (2003). The role of firm resources in returns to market deployment. Journal of Marketing Research, 305-309.

Song, M., Benedetto, A. D., \& Nason, R. W. (2007). Capabilities and financial performance: The moderating effect of strategic type. Journal of Academy of Marketing Science. 35, 18 34.

Song, M., Droge, C., Hanvanich, S., \& Calantone, R. (2005). Marketing and technology 
resource complementarity: An analysis of their interaction effect in two environmental contexts. Strategic Management Journal, 26(3), 259-276.

Talluri, S., Narasimhan, R. \& Nair, A.(2006). Vendor performance with supply risk: A chanceconstrained DEA approach. International Journal of Production Economics, 100 (2), 212 222.

Tan, K. C., Kannan, V. R., \& Narasimhan, R. (2007). The impact of operations capability on firm performance. International Journal of Production Research, 45(21), 5133-5156.

Tangpong, C. 2011. Content analytic approach to measuring operations and supply chain management. Journal of Operations Management 29, 627-638.

Theuvsen, L. (2004). Vertical integration in the European package tour business. Annals of Toursim Research, 31(2), 475-478.

Valand, T., \& Heide, M. (2005). Corporate Social Responsiveness:Exploring the Dynamics of 'Bad Episodes. European Management Journal, 23 (5), 495-506.

Vickery, S. K., Droge, C., \& Markland, R. E. (1993). Production competence and business strategy: do they affect business performance? Decision Science, 24, 435-455.

Vogel, D.J. (2005), Is there a market for virtue? The business case for corporate social responsibility, California Management Review, 47 (4), 19-45

Vorhies, D. W., \& Morgan, N. A. (2005). Benchmarking marketing capabilities for sustainable competitive advantage. Journal of Marketing, 69, 80-94.

Wernerfelt, B. (1984). A resource-based view of the firm. Strategic Management Journal, 5(2), 171-180.

WTO (World Tourism Organization). (1998). Introduction of Tourism. Madrid: WTO.

Wu, F., Yeniyurt, S., Kim, D., \& Cavusgil, S. T. (2006). The impact of information technology on supply chain capabilities and firm performance: A resource-based view. Industrial Marketing Management, 35(4), 493-504.

Xu, J., Li, B. \& Wu, D. (2009). Rough data envelopment analysis and its application to supply chain performance evaluation. International Journal of Production Economics, 122 (2), 628-638.

Yoshida, Y. and Fujimoto, H. (2004), Japanese-airport benchmarking with the DEA and endogenous-weight TFP methods: testing the criticism of overinvestment in Japanese regional airports, Transportation Research Part E: Logistics and Transportation Review, 40 (6), 533-546.

Yu, M-M., \& Lee B.C.Y., (2009). Efficiency and effectiveness of service business: Evidence from international tourist hotels in Taiwan, Tourism Management, 30 (4), 571-580.

Yu, W., R. Ramanathan and P. Nath (2014), The impacts of marketing and operations capabilities on financial performance in the UK retail sector: A resource-based perspective, Industrial Marketing Management, 43 (1), 25-31. 